\title{
Retalhos biográficos de uma professora iniciante
}

\author{
Biographical patches of a beginning teacher
}

Flaviane Coutinho Neves Americano Rego ${ }^{1}$ Helena Amaral da Fontoura ${ }^{2}$

\section{Resumo}

O presente artigo apresenta a narrativa de uma professora iniciante com base na reconstrução e ressignificação da vida e da formação. Neste sentido, o estudo traz a colaboração da professora no início da docência ao narrar experiências de tessituras biográficas em seus (per) cursos formativos que compõem a construção da profissão. Compreende a experiência à luz de Josso (2010) e do eu que emerge mediante o exercício de reflexividade crítica que possibilita ao sujeito desatar fios do passado e enredar laços futuros da sua existência humana. Por meio do dispositivo metodológico das narrativas, podemos resgatar os processos formativos que nos auxiliaram na construção pessoal e na composição da profissão professora. Autores como Freire (1991, 1996, 2021) Josso (2006, 2010) e Passeggi (2016) dão suporte teórico a este trabalho. As narrativas constituem uma relação afetiva com a formação, sendo possível repensar a trajetória de vida e formação, a reflexão das práticas e atuação docente em um movimento de transformação. As principais contribuições do estudo foram a compreensão dos processos de formação e a aparição do ser-sujeito em seus diversos registros, potencializando processos autoformativos e produzindo implicações que fortaleceram o desenvolvimento, assim como revelou um aspecto fundamental para o progresso da profissão docente, a reflexão crítica da prática pedagógica.

Palavras-chave: Narrativa. Professora iniciante. Tessitura biográfica. Processos autoformativos.

\begin{abstract}
This article presents a narrative of a beginning teacher based on reconstruction and resignification of life and training. The study brings teacher's collaboration at the beginning of teaching when she narrates experiences of biographical textures in her formative path that shows professional construction. It comprises the experience by

\footnotetext{
${ }^{1}$ Graduada em Pedagogia pela Faculdade de Formação de Professores da UERJ (2017). Mestre em Educação pelo Programa de Pós-Graduação Processos Formativos e Desigualdades Sociais da Faculdade de Formação de Professores da UERJ. Integrante do GRUPESq Formação de Professores, processos e práticas pedagógicas (CNPq). E-mail: flavicoutinho@hotmail.com ORCID: https://orcid.org/0000-0001-5441-3255

${ }^{2}$ Professora Titular Departamento de Educação Faculdade de Formação de Professores UERJ. Doutora em Ciência ENSP/Fiocruz (1997). Pós Doutora em Educação Universidad de Barcelona (2007). Pós Doutora em Educação UFMT (2017). Líder GRUPESq Formação de Professores, processos e práticas pedagógicas (CNPq), Pesquisadora 2 CNPq, Cientista do Nosso Estado (FAPERJ), Procientista (UERJ). ORCID: http://orcid.org/0000-0003-2795-8246
} 


\section{-Revista de Iniciação à Docência, v.6, n.2, 2021- \\ Publicação: dezembro, 2021 - ISSN 2525-4332}

Josso (2010) and the self that emerges through the exercise of critical reflexivity, which enables us to untie threads from the past and tangle future ties of human existence. Through methodological device of narratives, we can rescue the formative processes that helped us in the personal construction and composition of the teaching profession. Authors such as Freire (1991, 1996, 2021), Josso (2006, 2010) and Passeggi (2016) give theoretical support to this work. The narratives constitute an affective relationship with training, making possible to rethink trajectory of life and training, reflection of practices and teaching activities in a movement of transformation. The main contributions of the study were the understanding of training processes and the appearance of the beingsubject in its various records, enhancing self-training processes and producing implications that strengthened development, as well as revealing a fundamental aspect for the progress of the teaching profession, reflection criticism of pedagogical practice.

Keywords: Narrative. Beginning teacher. Biographical texture. Self-training processes.

\section{Introdução}

Em diálogo com o educador Paulo Freire (2021), apresentaremos 3 retalhos biográficos na composição da profissão docente, sobretudo na inserção e socialização profissional docente de uma professora iniciante, uma das autoras do presente trabalho. As falas dessa autora aparecem em itálico para caracterizar relatos de sua experiência de inserção na docência.

Narro 4 minhas experiências de formação e da profissão corroborando com Josso (2010) que considera que experiências são as vivências particulares dos sujeitos. À medida que somos capazes de refletir sobre o que se passou e sobre o que foi observado, tais vivências atingem o status de experiências, ou seja, quando há transformação. A autora também utiliza o conceito de experiências formadoras do sujeito e da profissão como aquelas que são significativas e que orientam a construção da narrativa. Neste caso, como aconteceu a formação? Como me formei professora? Como exerci a docência em meu primeiro ano como professora?

Falo de experiências formadoras porque o processo de desenvolvimento profissional docente me fez aprender a profissão a cada dia ao me transformar e transformar minhas práticas. Meu olhar para as vivências foi se transformando ao longo deste primeiro ano habitando o território escolar. E percebo o quanto me coloquei disponível aos processos. Descobri-me professora também na prática cotidiana buscando sentido para o que eu fazia e para quem eu fazia.

\footnotetext{
${ }^{3}$ A escrita no plural remete as duas autoras deste artigo.

${ }^{4}$ A escrita na primeira pessoa do singular, remete às experiências da pesquisa formação de Mestrado, de uma das autoras, na qual narra suas experiências de inserção e socialização profissional docente.
} 


\section{-Revista de Iniciação à Docência, v.6, n.2, 2021- \\ Publicação: dezembro, 2021 - ISSN 2525-4332}

Proponho com esta tecitura 5 explanar as experiências que emergem em mim sobre a construção de quem sou, professora, assim como a constituição da identidade docente neste período tão importante que é a fase de inserção profissional docente. Afirmo com Fontoura (2019) que ter um nome é uma marca de reconhecimento, por isso nosso nome Professor/a nos marca e nos faz reconhecidos/as.

Compreendemos que a identidade do/a professor/a é construída ao longo do processo de desenvolvimento profissional docente. Desta forma, entendemos que se trata de um ciclo no qual o /a professor/a cria deslocamentos ao ponto de compreender o seu papel na sala de aula e na escola. Tomar consciência de que, ao ocupar o espaço da sala de aula, o/a professor/a tem a possibilidade de colaborar com a construção de uma sociedade mais justa, solidária, democrática, perpassa o pensamento de Freire (2021) que declara que educar é um ato político, portanto, a educação não é transferência de saberes, mas uma construção entre os sujeitos envolvidos no processo de ensino e aprendizagem.

Reconhecemos com Marcelo (2009) que identidade profissional docente é um processo de construção do seu eu profissional, que evolui ao longo da sua carreira docente e que pode ser influenciada pela escola, pelas reformas e contextos políticos. "É marcado por contingências diversas, onde as características internas (como cada sujeito se vê e se reconhece) ligadas à sua autoimagem, e características externas (como é reconhecido por outros) se delineiam" (FONTOURA, 2019, p. 298).

Ao problematizar processos formativos, Nóvoa (2006) relata que a formação é algo que depende do próprio sujeito e se inscreve num processo de ser (experiências do nosso passado) e num processo de vir a ser (nossos projetos para o futuro). Passeggi (2016) ressalta que a narrativa é um fenômeno e uma abordagem de investigação e formação, pois parte das experiências e dos fenômenos humanos advindos das mesmas, portanto uma metodologia produtiva de descobertas de si e da profissão.

Através das narrativas da própria história, é possível problematizar e potencializar as experiências na medida em que a partir delas aconteça o ato de reflexividade que deve fazer parte do cotidiano de nossas vidas. Por meio dos questionamentos, indagando o que podemos fazer com aquilo que tem sido feito de nós, podemos produzir implicações que motivem o desenvolvimento pessoal e profissional; é através das constantes transformações que produzimos e apreendemos conhecimentos. Josso (2010) afirma que a narrativa torna-se um trampolim, um ponto de apoio para o salto do pensamento.

\footnotetext{
${ }^{5}$ Significado de Tecitura: Substantivo feminino - A reunião dos fios que se atravessam no tear (urdidura). Disponível em: https://www.dicio.com.br/tecitura/. Acesso em 17 de agosto de 2021.
} 


\section{Retalhos biográficos}

Os retalhos biográficos tecidos na trajetória individual e coletiva desvelam aprendizagens da formação e sobre a profissão. Deste modo, ao narrá-los, abro espaço para falar da Escola Municipal Vereador João da Silva Bezerra, a primeira escola na qual habitei desde o Jardim de Infância (atual Educação Infantil) até o Ensino Fundamental II. Foram 12 anos de caminhada neste espaço que me proporcionou aprendizado, crescimento e conquistas. Permitiu-me sonhar, ver e habitar o mundo com o meu olhar. Freire (2021) ressalta que a leitura do mundo precede a leitura da palavra, desta forma, ao desenvolver a realidade cotidiana da minha trajetória foi que pude me abrir para o mundo.

Josso (2010) destaca que a pesquisa-formação é uma metodologia que tem como cerne a experiência do sujeito como ponto de partida para a reflexão e transformação de si, que contempla a possibilidade de mudança das práticas, bem como dos sujeitos em formação. Dessa maneira, trago reflexões de como as experiências vivenciadas na prática docente contribuíram na minha inserção e socialização profissional docente. A pesquisaformação permite ao pesquisador criar sentidos e significados ao formar-se e transformar-se durante a ação da pesquisa, em vez de se distanciar ao tentar controlar e explicar os fenômenos.

A escola era literalmente a extensão da minha casa, bastava atravessar a rua que já estava dentro da escola. A escola também teve um papel afetivo fundamental na construção da minha identidade pessoal e profissional. Ecoa na memória a postura de professores/as, em diálogo com o que Freire (1996) diz sobre se fazer imprescindível que a prática do professor contemple o discurso. De nada adianta o discurso competente, se a ação pedagógica é impermeável a mudanças. Para alcançar essa postura de mudanças é preciso se abrir a reflexão da própria prática pedagógica e de si. Vivi experiências formadoras (JOSSO, 2010), que continuam reverberando em mim e na minha profissão.

Há um laço essencial que faz parte desta escolha pela profissão docente, um laço de parentesco (Josso, 2006) com minha avó Lúcia, aquela que mesmo não tendo a formação institucionalizada, me inspirou a voar mais alto, lutar e conquistar meus objetivos de vida. Aquela que ocupou o mesmo ambiente escolar que eu, mas em outra posição, minha avó foi merendeira desta escola até se aposentar. Minha avó não teve direito a uma formação institucionalizada, mas preservou o meu direito à educação.

Assim, parafraseando Freire (2021), estou construindo minha profissão como uma esperançosa que é fruto da educação pública e acredita na educação pública de qualidade como ferramenta para se pensar e reconstruir a sociedade em um mundo mais solidário, democrático, humano e justo. "Enquanto prática desveladora, gnosiológica, a educação sozinha, porém, não faz a transformação do mundo, mas esta a implica”. (FREIRE, 2021, p. 45). 
-Revista de Iniciação à Docência, v.6, n.2, 2021-
Publicação: dezembro, 2021 - ISSN 2525-4332

Freire (2021) ainda enfatiza que "enquanto necessidade ontológica, a esperança precisa da prática para tornar-se conteúdo histórico, é por isso que não há esperança na pura espera, nem tampouco se alcança o que se espera na espera pura, que vira assim, espera vã. (FREIRE, 2021, p. 15).

Segundo Freire (1991), é necessário estabelecer relações dialógicas de ensino e aprendizagem entre professor/a e aluno/a, acontecendo assim um encontro afetivo e democrático em que ao ensinar, o/a professor/a também aprende. O educador ainda afirma que "uma das melhores coisas que podemos experimentar na vida, é a boniteza em nossas relações mesmo, que de vez em quando salpicadas de descompassos que simplesmente comprovam nossa "gentetude"”. (FREIRE, 2021, p. 89).

Refletir sobre a reconstrução da sociedade significa agir para que prevaleça a formação de cidadãos críticos e reflexivos através de práticas problematizadoras. Quando me coloco como agente de transformação e crio relações com minhas crianças/ alunos e me dou ao direito de construir práticas outras que ultrapassem os muros da escola, percebo que estou contribuindo com os herdeiros do futuro sem me esquecer do quão importante é a participação deles no processo de ensino-aprendizagem.

Freire (1996) declara que "ensinar exige segurança, competência profissional e generosidade". (FREIRE, 2021, p. 47) O que significa que o professor não deve abrir mão da amorosidade no desenvolvimento do seu trabalho, característica essencial às relações educativas, evidenciando a humanidade e amorosidade no sentido de responsabilidade nas relações estabelecidas com outros sujeitos que também são atores de conhecimento.

Há um pensamento que ainda circula na sociedade, de que as crianças só são inseridas na Educação Infantil para brincar. Ora, elas aprendem brincando por meio de suas percepções e visão de mundo (FREIRE, 2021). Aposto na Educação Infantil como uma das etapas mais importantes se não a mais importante na vida do sujeito. É o começo de tudo.

No meu primeiro ano de inserção e socialização profissional docente fui professora regente de duas turmas multisseriadas de Educação Infantil, o que logo de início se apresentou como um dos maiores desafios enquanto professora novata. Como trabalhar os conteúdos e habilidades necessárias às três faixas etárias dentro de uma mesma turma?

Comecei a entender que embora minha turma fosse formada por crianças com a mesma faixa etária, mesmo assim eu deveria entendê-las como sujeitos únicos de vida e de conhecimento.

Podemos afirmar que a iniciação à docência é um ciclo crucial no desenvolvimento profissional docente, visto que não se trata de formação inicial nem de formação 
continuada, mas de fato do exercício da docência, no qual se vai aprendendo a ser professor/a dia após dia na escola, que é um lugar formativo.

Sobre essa questão, Marcelo (2009) salienta que:

As definições, tanto as mais recentes como as mais antigas, entendem o desenvolvimento profissional docente como um processo, que pode ser individual ou colectivo, mas que se deve contextualizar no local de trabalho do docente - a escola - e que contribui para o desenvolvimento das suas competências profissionais através de experiências de diferente índole, tanto formais como informais. (MARCELO, 2009, p. 10)

O autor ainda declara que opta pelo conceito de desenvolvimento profissional de professores porque compreende que a denominação desenvolvimento profissional se ajusta melhor à concepção do professor enquanto profissional do ensino e porque o conceito de "desenvolvimento" tem um sentido de evolução e continuidade que suplanta a tradicional justaposição entre formação inicial e formação contínua dos professores.

O desafio fez com que eu me deslocasse e criasse estratégias que pudessem me auxiliar na construção do meu papel enquanto professora. Comecei a refletir sobre minhas práticas. O que hoje eu não alcancei com as crianças de três anos que amanhã eu posso alcançar? Ou então o que eu não alcancei com as crianças de quatro e cinco anos que eu posso alcançar amanhã? Esse movimento não foi fácil, mas foi possível porque me coloquei no direito de aprender diariamente o meu ofício de ensinar.

Freire (1991) nos instiga a pensar na construção da profissão docente quando afirma que "ninguém começa a ser educador numa certa terça-feira às 4 horas da tarde... Ninguém nasce educador ou marcado para ser educador. A gente se faz educador, na prática e na reflexão sobre a prática". (FREIRE, 1991, pág. 58) Por isso a importância do desenvolvimento profissional na construção da identidade docente. O fazer-se professor se dá ao longo da caminhada da vida, nos processos de desdobramento da formação e durante a prática docente, o que significa dizer que o professor vai aprendendo a profissão a cada dia e que continua e continuará se compondo professor à medida que as experiências vividas no cotidiano ato de ensinar vão the atravessando e causando os deslocamentos necessários à sua atuação através do movimento de reflexão e transformação.

Fontoura (2019) destaca três aspectos da construção da identidade docente: individual, desenvolvimento profissional e políticas públicas. A autora ainda afirma que ser professor envolve ensinar e aprender como tarefas diárias próprias do fazer docente, considerando os níveis diferentes e includentes da construção identitária.

Ao assumir que o desenvolvimento profissional é um processo que se vai construindo à medida que os professores ganham experiência, sabedoria e consciência profissional, Marcelo (2009) ressalta a importância do papel que a identidade profissional 


\section{-Revista de Iniciação à Docência, v.6, n.2, 2021- \\ Publicação: dezembro, 2021 - ISSN 2525-4332}

docente joga no desenvolvimento profissional e nos processos de mudança e melhoria da profissão docente.

Ao longo do desenvolvimento profissional, o docente vai adquirindo saberes e habilidades concernentes ao ofício de ensinar, uma vez que também constrói seus saberes na prática diária; o/a professor/a aprende a fazer fazendo e criando deslocamentos mediante reflexão do seu trabalho. De acordo com Tardif (2014), o saber dos docentes não é uma coleção de conteúdos intelectuais definidos de uma vez por todas, mas um processo em composição ao longo da carreira profissional na qual o professor aprende gradativamente o domínio do seu ambiente de trabalho, ao se inserir nele e o interiorizar por meio de normas de ação que consequentemente se tornam componentes de sua "consciência prática”.

O ser humano, sujeito inacabado como já dizia Paulo Freire (1996) tem a consciência de sua inconclusão e, portanto, deve se manter aberto às constantes aprendizagens e mudanças que o ato de ensinar lhe proporciona e permite através das experiências sejam elas repetidas ou não.

Dia após dia buscava colocar em prática uma educação que dialogasse com a realidade das minhas crianças e que me possibilitasse criar relações de parceira com elas, como de fato aconteceu. Os processos que vivenciei ao longo deste primeiro ano de docência são parte de mim, também me constituíram quem sou. Quando iniciei a apresentação do alfabeto, eu sabia que queria fazer diferente do que eu já havia visto convidando as crianças a embarcarem comigo numa viagem de imaginação e criação. Não consegui realizar a apresentação do alfabeto todo com esta dinâmica, mas refletindo sobre esse processo, considero ter realizado como me propus a realizar, ofertando o melhor que eu poderia na ocasião.

Figura 1 - Apresentação da letra F/f - Fada

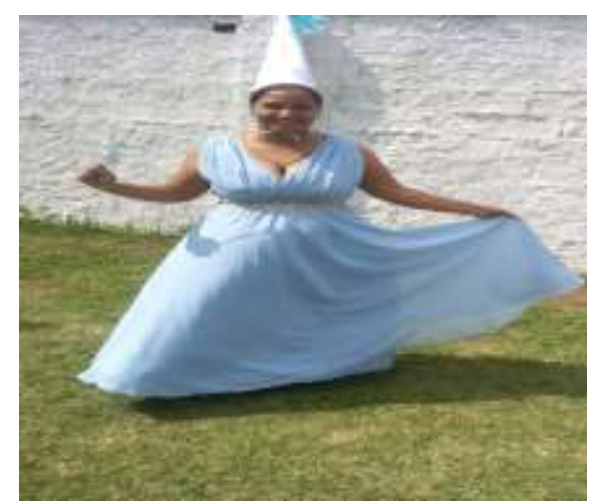

Fonte: Arquivo pessoal, 2018.

Quando me vesti de fada para apresentar-lhes a letra $\mathrm{F} / \mathrm{f}$ recebi tantos desejos que mesmo sabendo não poder torná-los realidade naquele momento, guardei-os em meu coração. Quando a Boneca Berenice visitou a escola para lhes apresentar a letra B/b 


\section{-Revista de Iniciação à Docência, v.6, n.2, 2021- \\ Publicação: dezembro, 2021 - ISSN 2525-4332}

levou consigo uma bola para brincar com as crianças no pátio. Além de aproveitar o espaço para outras atividades como música e dança. Lembro-me que algumas crianças afirmavam que a boneca Berenice era eu, mas outras crianças de fato acreditaram na visita de uma boneca. Assim como na proposta da atividade com a fada, a visita da Boneca Berenice era um convite a ludicidade para a apresentação de uma das letras do alfabeto, na qual eu conseguisse proporcionar momentos em que a criatividade e a curiosidade das crianças pudessem aflorar, o que segundo Freire (2021) compõe a ética da educação.

Figura 2 - Apresentação da letra B/b - Boneca Berenice

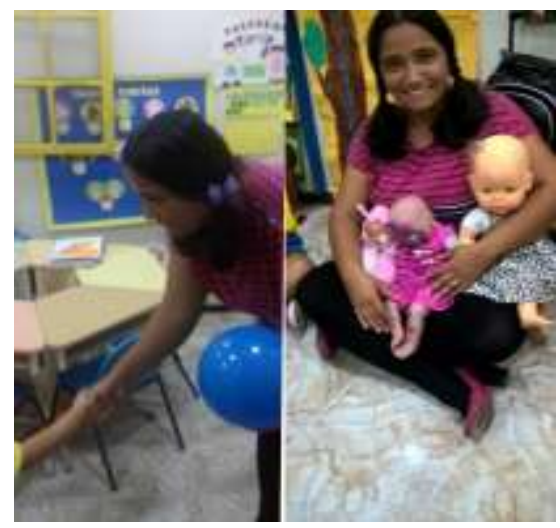

Fonte: Arquivo pessoal, 2018.

A cada letra apresentada nosso alfabeto ilustrado ganhava vida a partir do desenho e pintura das crianças. O alfabeto foi construído a partir do que eles conheciam. Procurava desenvolver um trabalho que partisse do aluno, mas que pudesse ser expandido para o todo, ou seja, reconhecer a visão de mundo e ampliá-la, como nos ressalta Freire (2021).

Figura 3 - Alfabeto ilustrado pelas crianças

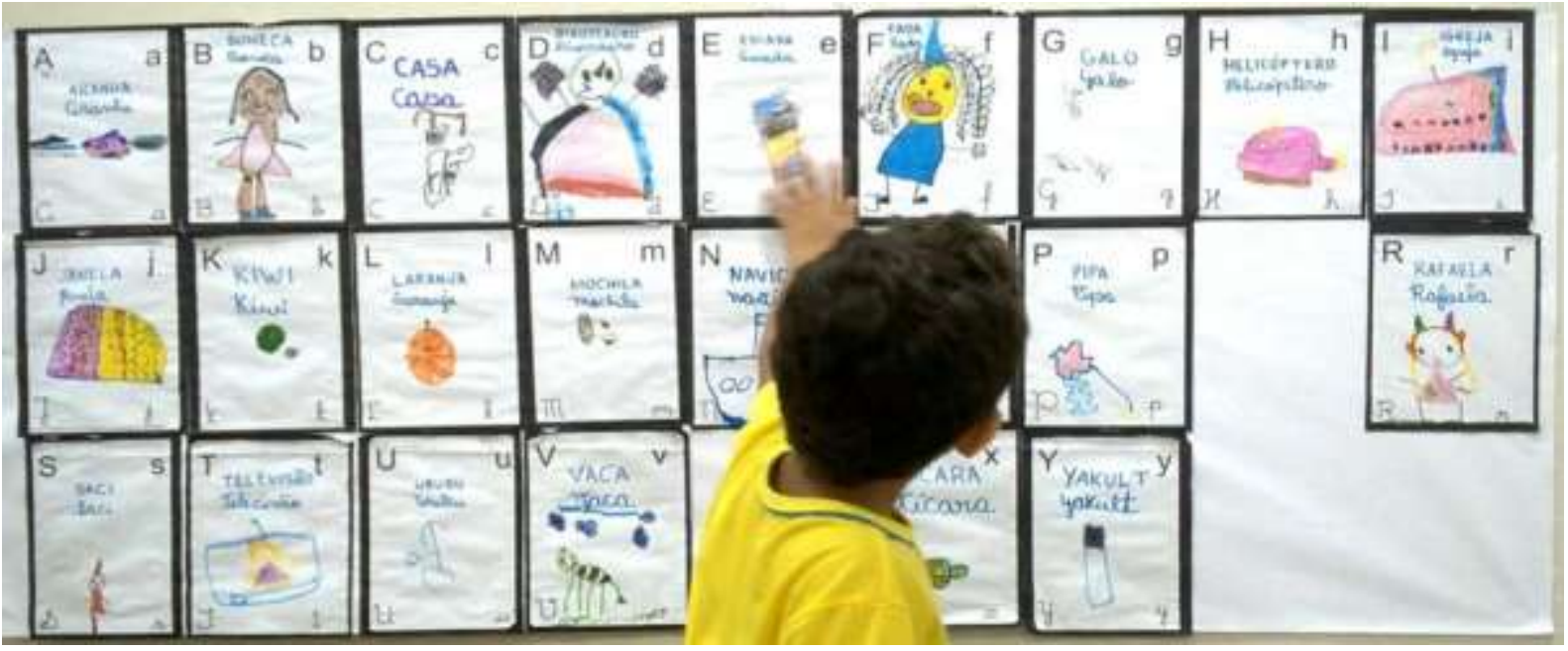

Fonte: Arquivo pessoal, 2018. 


\section{-Revista de Iniciação à Docência, v.6, n.2, 2021- \\ Publicação: dezembro, 2021 - ISSN 2525-4332}

Percebemos a boneca e a fada ilustradas no alfabeto confeccionado pelas crianças. Na letra $\mathrm{M} / \mathrm{m}$, vemos uma mochila desenhada. Objeto que fazia parte da rotina escolar de todas as crianças. Na ocasião como se aproximava os festejos juninos, fomos ao refeitório fazer um bolo de milho, uma das comidas típicas desta época do ano. Lembro que fizemos o bolo logo no início do nosso encontro para que desse tempo de ficar pronto para o horário do nosso lanche. Uma das crianças disse que não gostava de bolo de milho e não queria comer. Porém com o passar do tempo ao ver as outras crianças comendo, ele pediu para provar e para minha surpresa não só provou como repetiu. A ilustração do alfabeto se deu de forma livre, conforme o que a criança conhecida e o que era convidada a conhecer. Eu poderia ter me frustrado se naquela atividade culinária o que importasse fosse apenas a letra $\mathrm{M} / \mathrm{n}$, mas a atividade tinha como proposta possibilitar outros conhecimentos, além claro da letra $\mathrm{M} / \mathrm{m}$ por ser a letra inicial do milho. Com esta atividade pude explicar os diferentes modos das unidades de medida, citando a quantidade dos ingredientes como: litro, colher, xícara e etc. Aproveitando para destacar a importância deste conhecimento para a vida cotidiana das crianças. Além disso, trabalhamos gênero textual ao realizar a escrita da receita do bolo e colocar o cartaz na sala. Acredito que as crianças se interessem por aquilo que lhes chamam atenção, atividades prazerosas que instiguem a imaginação, criatividade, participação. Mas para desenvolver essa prática pedagógica dá trabalho e requer preparação. Nem sempre estaremos disponíveis, mas temos que pensar que cada dia é uma oportunidade de fazer diferente e oferecer o melhor para nossas crianças/alunos.

Falando ainda nesta atividade, lembrei-me que não mostrei para eles uma espiga de milho, apenas o milho enlatado. Então por isso considero que em práticas futuras primeiramente começaria pela espiga de milho. Parece algo simples, mas que faz sentido para a sequência didática da atividade. Acredito que essa busca por práticas outras e pensando em melhorar o fazer docente considerando a profissão como desafiadora que nos permite esta exploração ainda mais no início da carreira, uma espécie de ensaio mesmo. Na letra $R$, a criança se desenhou.

Desenvolvia textos coletivos com o objetivo de proporcionar a participação de todas as crianças nas atividades coletivas. Elas eram as narradoras das histórias e eu a escriba. Ao terminar de escrever a história no cartaz, lia a história e a ilustração ficava por conta da criatividade delas. Uma das histórias produzidas pela turma foi o dia que a Fada visitou a escola para lhes apresentar a letra F/f. 
Figura 4- As crianças com a Fada

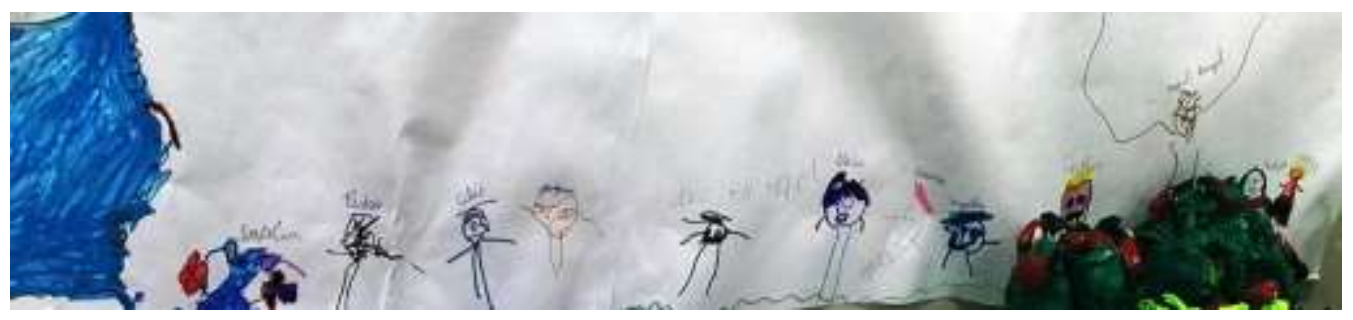

Fonte: Arquivo pessoal, 2018.

Ao longo do ano confeccionamos alguns brinquedos com materiais de sucata, como o pião que foi feito com Cd usado, bilboquê que foi elaborado com garrafas pet, peteca com jornal, carrinhos construídos com caixa de leite, sanfona que também foi produzida com caixa de leite e que foi o acessório que os meninos utilizaram para dançar a música "Entra na roda” na festa junina.

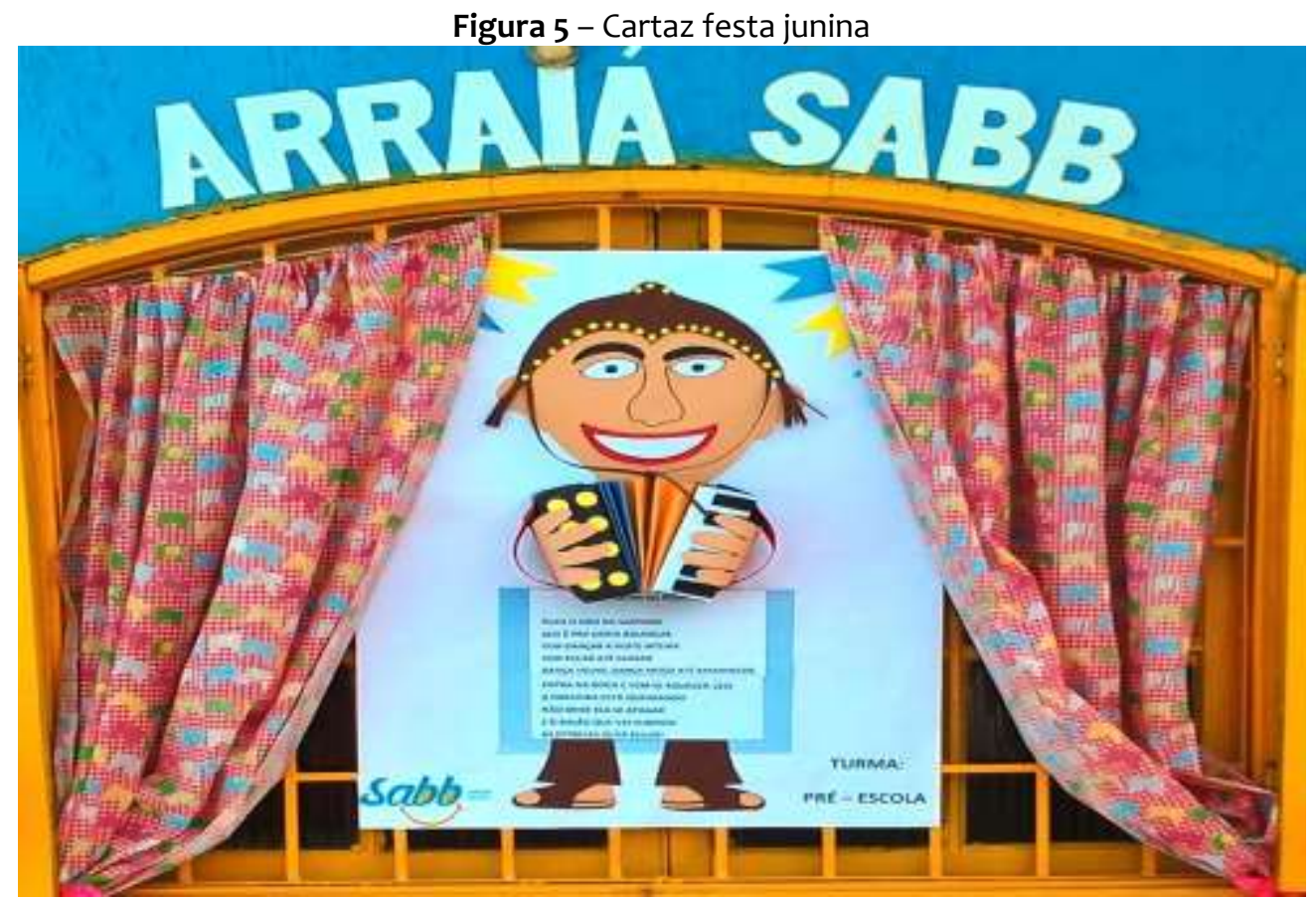

Fonte: Arquivo pessoal, 2018. 


\section{-Revista de Iniciação à Docência, v.6, n.2, 2021- \\ Publicação: dezembro, 2021 - ISSN 2525-4332}

Figura 6 - Brinquedo pião confeccionado com Cd usado

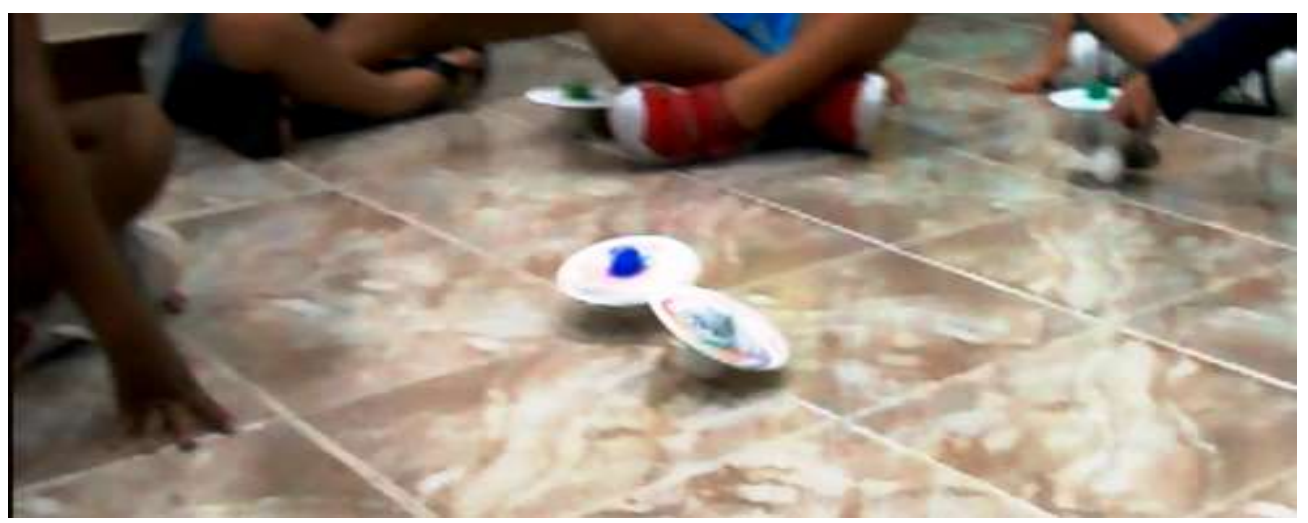

Fonte: Arquivo pessoal, 2018.

Sobre esta possibilidade de narrar minhas experiências, enquanto pesquisaformação, Passeggi (2016) afirma:

Essa potencialidade formadora de fazer experiências, refletir sobre elas para aprender sobre nós mesmos e o mundo, torna inseparável o sujeito e o objeto de conhecimento. Ou seja, é preciso se expor, sem medo de padecer sob o impacto da experiência para poder dela tirar lições para a vida e aprender com ela sobre nós mesmos. (PASSEGGI, 2016, p. 76)

Freire (1996) nos diz que ensinar exige saber ouvir. E acrescenta que se, na verdade, "o sonho que nos anima é democrático e solidário, não é falando aos outros, de cima para baixo, sobretudo, como se fôssemos os portadores da verdade a ser transmitida aos demais, que aprendemos a escutar, mas é escutando que aprendemos a falar com eles". FREIRE, 1996, p. 58)

A roda de conversas que acontecia diariamente era um momento oportuno para nossa troca e construção de saberes, nela tínhamos cantoria, as crianças me contavam com qual sentimento chegavam à escola naquele dia. Tinha o momento em que eu contava histórias para eles e eles também contavam histórias para mim, seja através da leitura de figuras dos livros infantis seja por meio de suas próprias histórias inventadas. Ali eu tinha oportunidade de conhecê-los cada vez mais.

Uma das tramas (FREIRE, 2021) que apresento aqui é de uma criança que chegava atrasada todos os dias. Este atraso me incomodava porque eu pensava que ele estava sendo prejudicado e porque atrapalharia o momento já iniciado, mas quando José ${ }^{6}$ chegava sempre tinha uma história para contar. Era uma criança de quatro anos, mas já possuía um rico vocabulário. De acordo com algumas palavras que ele falava eu o instigava perguntando o significado delas, para minha surpresa ele dava a explicação dele, que confesso às vezes me deixava curiosa. Era o significado que ele dava a partir da percepção dele. Eu ficava encantada, inclusive disse que faria um dicionário com as

\footnotetext{
${ }^{6}$ Optamos por chamar a criança por um nome fictício para preservação da sua imagem.
} 


\section{-Revista de Iniciação à Docência, v.6, n.2, 2021- \\ Publicação: dezembro, 2021 - ISSN 2525-4332}

palavras que ele trazia. O dicionário não saiu, mas José marcou minha profissão com os retalhos deixados em mim.

Normalmente, eu era abordada por José que naquela época morava com o pai e os avós paternos. Geralmente, estamos habituados com outra situação, mais uma vez a educação e suas complexidades, já que o modelo de família também passou por mudanças. Não me via como mãe dele e não desejava ocupar esse lugar, mas não poderia simplesmente fingir que tudo estava bem, porque não estava.

Percebia o pai muito presente, participava das reuniões, no entanto era ele que chegava todo dia atrasado. Quando me abordava dizia que me amava me abraçava sempre muito carinhoso e repetia que sentia saudades de sua mãe. Era difícil para mim aquela situação, porque não estamos preparados para lidar com as inúmeras questões que acontecem no cotidiano escolar e essa questão como tantas outras ultrapassava os limites da escola. Mesmo assim o ouvia, acolhia o que tinha para falar, conversávamos e retribuía o afeto. Mas aí que entra a amorosidade de Paulo Freire (2021). Esta amorosidade não significa passar a mão na cabeça ou tampouco apenas demonstrar e/ou retribuir afeto, na verdade a amorosidade tem a ver com a contribuição para a evolução do indivíduo.

Neste sentido buscava conversar com José sobre tal questão e o que ele pensava de morar com o pai, porque aquela era a situação que se apresentava naquele momento. Aos poucos ele me contava que era legal morar com o pai e que o amava, era nítido a relação entre os dois. E assim foram passando um dia após o outro. Não é uma questão de normalizar a situação, mas em reflexão perceber o lado bom das coisas. Fácil não é, mas é possível e pode começar a ser construído a partir da educação das infâncias, assim a possibilidade de reduzir as frustrações da vida aumenta.

A educação engloba uma gama de fatores, que vai além do conteúdo a ser ensinado e das habilidades a serem apreendidas. Destaque para as relações estabelecidas na escola com as crianças, com os pares, com os pais e/ou responsáveis. Freire (2021) nos convida a pensar que a educação perpassa a humanidade, no sentido da responsabilidade com os outros que tem a ver com a ética do ser humano, e isso se aplica na escola, na sala de aula, através de práticas pedagógicas na qual o/a professor/a compreende a finalidade do que se faz e para quem faz.

Corroborando com Freire (1991), o professor tem o papel de criar relações dialógicas de ensino-aprendizagem, acontecendo assim um encontro democrático e afetivo, em que professor/a também aprende.

Sobre isso, Freire (1996) destaca:

É preciso que, desde os começos do processo, vá ficando cada vez mais claro que, embora diferentes entre si, quem forma se forma e reforma ao formar e quem é formado forma-se e forma ao ser formado. É nesse sentido que ensinar 


\section{-Revista de Iniciação à Docência, v.6, n.2, 2021- Publicação: dezembro, 2021 - ISSN 2525-4332}

não é transferir conhecimentos, conteúdos, nem formar é a ação pela qual um sujeito criador dá forma, estilo ou alma a um corpo indeciso e acomodado. Não há docência sem discência, as duas se explicam e seus sujeitos, apesar das diferenças que os conotam, não se reduzem à condição de objeto, um do outro. Quem ensina aprende ao ensinar e quem aprende ensina ao aprender. (FREIRE, 1996, p. 13)

Foi necessário um exercício diário para compreender e enxergar minhas crianças como sujeitos inseridos socialmente, culturalmente, espiritualmente; a criança é um ser de conhecimento e de sonhos, portanto como nos ressalta Freire (1997) ensinar é um ato criador, um ato crítico, não mecânico. A curiosidade do/a professor/a e dos alunos, em ação, se encontra na base do ensinar-aprender. Conhecer o aluno e suas necessidades para depois sim pensar em dialogar com os conteúdos e habilidades a serem desenvolvidas. Valorizar o processo e não apenas o resultado final.

Para Freire (1997), não é possível ao/a educador/a desconhecer, subestimar ou negar os "saberes de experiências feitos" com que os educandos chegam à escola.

Essa peculiaridade se fazia presente na minha sala de aula, mas afirmo que foi uma construção diária, pois ao estarem inseridos em contextos diversos fui provocada a transformar minha prática diária. Eu fazia plano de aula, mas não era engessado, o que me possibilitou alterar o percurso algumas vezes quando necessário.

Ao longo do desenvolvimento profissional, o docente vai adquirindo saberes e habilidades concernentes ao ofício de ensinar, uma vez que também constrói seus saberes na prática diária; o (a) professor (a) aprende a fazer fazendo e criando deslocamentos mediante a reflexão sobre seu trabalho.

"Construir a identidade profissional docente acontece na confluência de momentos de prática e de teoria, em que o professor, sujeito de sua formação, constrói saberes superando dicotomias e fragmentações tão características de nossos processos educacionais". FONTOURA, 2019, p. 298)

Compreendemos que a identidade do/a professor/a é construída ao longo do processo de desenvolvimento profissional docente. Desta forma, entendemos que se trata de um ciclo no qual o/a professor/a cria deslocamentos ao ponto de compreender o seu papel na sala de aula e na escola. Tomar consciência de que, ao ocupar o espaço da sala de aula, o/a professor/a tem a possibilidade de colaborar com a construção de uma sociedade mais justa, solidária, democrática, perpassa o pensamento de Freire (2021, p. 78) que declara que "ensinar é um ato criador, um ato crítico e não mecânico", portanto, um ato político. $O$ autor ainda acrescenta que a educação não é mera transferência de saberes, mas uma construção entre os sujeitos envolvidos no processo de ensino e aprendizagem.

Considero que meu trabalho durante o primeiro ano na docência foi positivo porque tive o apoio principalmente da minha diretora. Porque de verdade muitas vezes não acreditava que daria conta, mas ela me fazia acreditar que era possível. Não posso 
-Revista de Iniciação à Docência, v.6, n.2, 2021-

Publicação: dezembro, 2021 - ISSN 2525-4332

deixar de citar Professora Cláudia que esteve comigo durante quase todo ano, além de me auxiliar especificamente com uma das crianças ela me ajudava nas atividades com as duas turmas.

\section{Considerações (in)conclusivas}

Paulo Freire deixou-nos um legado de suma importância para o âmbito educacional e para a humanidade de forma geral. Ele foi e ainda é uma referência para a educação. Se conseguirmos construir práticas problematizadoras enquanto agentes de transformação seremos capazes de promover a educação como uma ação transformadora. Ao refletir sobre meus processos de inserção e socialização profissional docente percebi que em muitas práticas pedagógicas eu me aproximava do educador Paulo Freire, em outras nem tanto.

O que ressalto é que na maioria das vezes tentava colocar em prática o que havia aprendido na teoria, mas quando assumi o lugar de pesquisadora durante o curso de mestrado numa dimensão de pesquisa-formação compreendi que também construí teorias por meio de minhas práticas.

É necessário que haja a associação do professor-pesquisador-professor. Afinal ao dar aula o professor necessita fazer uso de diversas habilidades. Corroborando com Leite e Fontoura (2017) quando afirmam que o professor da educação básica é um produtor de conhecimentos, ao ensinar mobiliza saberes, adaptando-os e transformando-os pelo e para o trabalho.

A dimensão da experiência engloba o sujeito biográfico, epistêmico e profissional. Assim, ao tecer uma narrativa é possível ao sujeito mobilizar uma série de conhecimentos sobre si, sobre a profissão e sobre a vida. Por isso reafirmamos a beleza da narrativa como possibilidade de criação e liberdade.

Freire (2021) afirma que não é possível viver, muito menos existir sem correr riscos. O fundamental é nos prepararmos para saber vivê-los bem. A vida é feita de escolhas e não é diferente na profissão professor/a. O/a professor/a tem o poder em sua voz, em suas mãos, em seus gestos, por isso pode escolher qual formação vai fundamentar suas práticas em sala de aula: cooperação ou competição, saberes significativos ou memorizados, se vai incentivar sonhos ou desestimulá-los. Por isso faz-se essencial que o professor tenha consciência e assuma seu papel enquanto agente transformador, narrador e sujeito de sua história pessoal e profissional concordando com Freire (2021) que afirma que o trabalho do professor ultrapassa a mera transmissão do conhecimento.

O primeiro ano da docência foi aproveitado, mas com o amadurecimento atual afirmo que o campo poderia ter sido mais explorado. E como é rico nosso espaço da 


\section{-Revista de Iniciação à Docência, v.6, n.2, 2021- \\ Publicação: dezembro, 2021 - ISSN 2525-4332}

sala de aula. É verdade que temos que cumprir o planejamento e o currículo para alcançar as habilidades. Afinal, os pais nos cobram isso, a escola também. Mas cabe a nós enquanto professores responsáveis pela turma decidir didaticamente como iremos desenvolver nossa prática e de que forma queremos alcançar nossos/as alunos/as. Se através da educação problematizadora ou bancária como nos ressalta Freire (2021).

Ao problematizar os processos da iniciação à docência percebo as transformações enquanto sujeito de vida e de conhecimento. Ao ocupar o lugar de professora iniciante, vivenciar experiências únicas da profissão e me dedicar ao tema, evidencio esse estágio da carreira docente como a mais importante, porque presumo que seja exatamente nessa etapa em que o/a professor/a iniciante faz a escolha de permanecer ou não na profissão. Neste sentido, ainda fazendo parte desse estágio, já que estive como regente de turma apenas durante o ano letivo de 2018, eu afirmo o meu desejo de prosseguir como professora, pois considero ter sido privilegiada neste primeiro ano de inserção e socialização profissional docente.

Freire (2021) destaca que fazendo e refazendo-se no processo de fazer a história como sujeitos e objetos, mulheres e homens, virando seres de inserção no mundo e não da pura adaptação ao mundo, terminaram por ter no sonho um motor da história. Não há mudança sem sonho, não há sonho sem esperança.

Afirmamos que o período inicial da docência se revelou como possibilidade de criação, de fazeres outros na profissão, com o desejo de colocar em prática uma educação emancipatória, democrática, humanizada e transformadora. Pensar e agir para uma educação que rompa os limites dos muros da escola e que assim seja possível construir uma sociedade mais justa e igualitária. Freire (2021) afirma que uma das bonitezas da prática educativa é que não é possível vivê-la sem correr riscos. O autor ainda destaca a essência da educação como prática da liberdade.

Declaramos a beleza da narrativa como peculiaridade da construção e reconstrução da humanidade. O patrono da educação, Paulo Freire (2021) já trazia em seus retalhos biográficos a boniteza da narrativa. Assim surgiu a inspiração para este artigo em diálogo com seu pensamento que para nós é considerado herança.

Afirmamos também a relevância da escola enquanto espaço formativo, porque o/a educador/a também se forma na escola no exercício diário da sua prática docente. Declaramos a urgência em transformar a palavra esperança em verbo esperançar como tarefa do educador porque nós professores/as também somos a escola.

Ademais, proclamamos a relevância em fortalecer uma educação de valorização de professores reflexivos, para que esses possam exercitar a liberdade e competência de criação em sua profissão. 


\section{Agradecimentos}

À Fundação de Amparo à Pesquisa do Estado do Rio de Janeiro (FAPERJ), pelo apoio e incentivo à pesquisa, pela bolsa de Mestrado concedida.

\section{Referências}

FONTOURA, Helena Amaral. Meu nome é professor/a: sobre aprender a docência e identidades. Rev. Educ. Públ. Cuiabá, v. 28, n. 68, p. 297-310, maio/ago. 2019. Disponível em: https://periodicoscientificos.ufmt.br/ojs/index.php/educacaopublica/article/view/8391. Acesso em: 15 out. 2020.

FREIRE, Paulo. A Educação na cidade. São Paulo: Cortez, 1991.

FREIRE, Paulo. Pedagogia da autonomia: saberes necessários à prática educativa. 5. ed. São Paulo: Paz e Terra, 1996. (coleção Leitura)

FREIRE, Paulo, 1921-1997. $29^{\mathrm{a}}$ ed. Pedagogia da Esperança: um reencontro com a pedagogia do oprimido / Paulo Freire: prefácio de Leonardo Boff; notas de Ana Maria Araújo Freire. - 29a ed. São Paulo / Rio de Janeiro: Paz e Terra, 2021.

JOSSO, Marie Christine. As figuras de ligação nos relatos de formação: ligações formadoras, deformadoras e transformadoras. Educ. Pesqui., São Paulo, v. 32, n. 2, p. 373383, Ago. 2006. DOI: http://dx.doi.org/10.1590/S1517-97022006000200012. Disponível em: <http://www.scielo.br/scielo.php?script=sci_arttext\&pid=S151797022006000200012\&lng=en\&nrm=iso>. Acesso em: 3 fev. 2021.

JOSSO, Marie Christine. Experiências de vida e formação. Tradução de José Cláudio, Júlia Ferreira; revisão científica Maria da Conceição Passeggi, Marie Christine Josso. 2.ed. re. e ampl. Natal: EDUFRN; São Paulo: Paulus, 2010. (Coleção Pesquisa (auto)biográfica \& Educação. Série Clássicos da Histórias de Vida)

LEITE, Vania Finholdt Angelo; FONTOURA, Helena Amaral. Parceria entre universidade e escola básica: a experiência da Faculdade de Formação de Professores / UERJ. In Giseli Barreto da Cruz, Ana Teresa de C. C. de Oliveira, Maria das G. C. de A. Nascimento (organizadoras). Ensino de didática: entre ressignificações e possibilidades. Curitiba: CRV, 2017. p. 103-120.

MARCELO, Carlos. Desenvolvimento Profissional Docente: passado e futuro. Sísifo. Revista de Ciências da Educação, 08, p. 7-22, 2009. Disponível em: http://www.unitau.br/files/arquivos/category_1/MARCELO__Desenvolvimento_Profissio nal_Docente_passado_e_futuro_1386180263.pdf. Acesso em: 5 Ago. 2020.

NÓVOA, Antônio. Desafios do trabalho do professor no mundo contemporâneo. Nada substitui o bom professor. Palestra proferida no Sindicato dos Professores de São Paulo, São Paulo, 2006. Disponível em:

http://www.sinprosp.org.br/arquivos/novoa/livreto_novoa.pdf. Acesso em: 01 fev. 2020. 
PASSEGGI, Maria da Conceição. Narrativas da experiência na pesquisa-formação: do sujeito epistêmico ao sujeito biográfico. Rev. Roteiro, Joaçaba, v.41, n.1, p. 67-86, jan/abr. 2016.

TARDIF, Maurice. Saberes docentes e formação profissional / Maurice Tardif. 17. ed. Petrópolis, RJ: Vozes, 2014.

Recebido: 30.08 .2021

Aprovado: 22.11.2021 